University of Louisville

ThinkIR: The University of Louisville's Institutional Repository

8-1948

\title{
A study of the reading of fifty teachers of Louisville and Jefferson County during the year of 1947-1948.
}

Glenn Gray

University of Louisville

Follow this and additional works at: https://ir.library.louisville.edu/etd

Part of the Education Commons

\section{Recommended Citation}

Gray, Glenn, "A study of the reading of fifty teachers of Louisville and Jefferson County during the year of 1947-1948." (1948). Electronic Theses and Dissertations. Paper 1979.

https://doi.org/10.18297/etd/1979

This Master's Thesis is brought to you for free and open access by ThinkIR: The University of Louisville's Institutional Repository. It has been accepted for inclusion in Electronic Theses and Dissertations by an authorized administrator of ThinkIR: The University of Louisville's Institutional Repository. This title appears here courtesy of the author, who has retained all other copyrights. For more information, please contact thinkir@louisville.edu. 
UNIVERSITY OF LOUISVIIIE

A STUDY OF THE READING OF FIFTY TEACHERS

OF LOUISVIILE AND JEFFERSON COUNTY

DURING THE YEAR OF 1947-48

A Professional Paper submitted to the Faculty of the Graduate School of the University of

Louisville in Partial Fulfillment of the

Requirements for the Degree of Master

in the Department of

Education

Glenn Gray

1948 
WAME OF STUDENI_ Glenn Gray

TITIE OF PROFESSIONAI PAPER: A STUDY OF THE READING OF FIFTY TEACHERS OF LOUISVIILE AND JEFFERSON COUNTY DURING THE YEAR OF 1947-48.

APPROVED BY THE READING COMAITTEE COMPOSED OF THE FOLLOWING MEQBERS:

Clyde W. Smith

Ruth Dunn

ADVISOR:

J. J. Oppenheimer

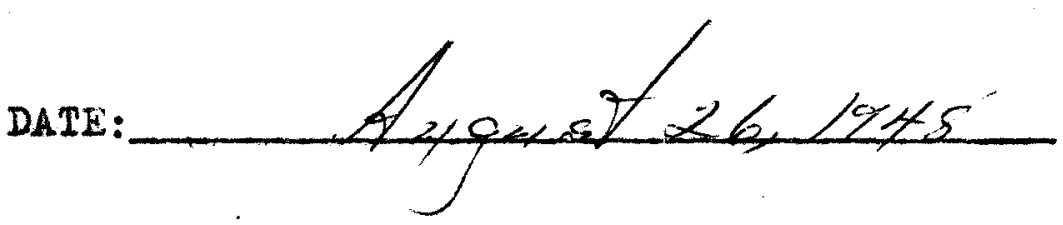




\section{Acknowledgments}

are made to the teachers and librariens whose helpfulness made possible the completion of this study; to M1ss Fowler who is not blind to faults nor lacks the courage to mention them as she exhorts teachers to dedicate themselves to a goal and manifest that dedication to the ideal; and to the multitude of teachers who make themselves of no reputation but accept the task and title and live the latter to the full. 
A STUDY OF THE READING OF FIFTY TEACHERS

OF IOUISVILLE AND JEFFERSON COUNTY

DURING THE YEAR OF

$1947-48$ 


\section{TABLE OF CONTENTS}


TABIR OF CONTENTS

INTRODUCTION

SECTION

I. PURPOSE OF THE STUDY

II. SCOPE AND METHOD OF THE STUDY

III. FINDINGS

IV. CONCIUSIONS DRAWN FROM THE FINDINGS

V. SUGGESTIONS FOR CONTINUED STUDY

VI. BIBIIOGRAPHY 
INTRODUCTION 
Teacher Reading is the topic of this professional paper which has been written to fulfill partially the requirements for the Degree of Master in Education for the University of Louisville, Louisville, Kentucky.

The purpose of this study is neither to condone nor to condemn teachers in their discrimination or quantity of reading, but is, instead, a rather limited survey to portray the extent and type of reading done by teachers in the schools of Jefferson County and the city of Loulstille during the year 1947-1948.

Any study worth the making must be supported by numerous facts and will require considerable time or space for presentation. The writer feels compelled to admit that this study is inadequate in several respects. First,a one-year study could not give a true account of any teacher's reading. Second, the human element so often affecting the scope and cholce of reading is touched only sketchily.Third, no data was accumulated to reveal the extent of reading and preferences of different age groups. Fourth, the teacher's proximity to libraries and the type of material more easily avallable could not be obtained accurately in the time allotted.And last, only two teachers on each grade level have furnished the findings and conclusions derived at in this paper. 
However, an attempt was made to touch upon most of the above phases and, in addition, to counterbalance each teacher used in the survey who now is enrolled in a professional course with one who has not been so engaged during the year 1947-1948.

Also, some conclusions present themselves 1mmediately regarding the differentiation between the breadth and amount of reading teachers in the Louisville schools and those in Jefferson County. No hint of censure is intended, for will Rogers measured every level of education when he stated so truthfully, "You know, Percy, everybody is 1gnorant only on different subjects" But some effort is made toward a plausible explanation.

Therefore, the aim of this paper evolves to be a survey showing what teachers read, that for the most part they are as well-1nformed as the average run-of-the -mill citizen and in some instances better, that all teachers do not accept gratis raises in pay without some effort at self-improvement, that human elements such as limited time,outside duties,illness (either personal or family) affect teacher reading, and that city teachers as a whole read more widely than do county teachers.

\footnotetext{
1.Rogers, Will. Illiterate Dizest page 64 . As quoted in Burton Stevenson's Home Book of Quotations page 959. Dodd Mead and Company, New York.
} 
If this paper in any way proves to be of help to the teacher either to uphold the confirmed belief which the writer has that teachers in the main are alive, interested individuals, to ald the teacher in the obtaining of libraries in the schools,or to stimulate reading, then,will the time spent on this paper be justifled and my desire be realized. 
SECTION

I

PURPOSE OF THE STUDY 
PURPOSE OF THE STUDY

Reading as the truest source of knowledge long has been a controversial issue and we should not like the teacher to be a mere receiver and collector of authors'ideas. There is, of course, the posstbility of becoming overstuffed with books and it is seemingly wise to heed Milton's lines in Paradise Regained-

"Who reads

Incessantly, and to his reading brings not

A spirit and judgment equal or superior

Uncertain and unsettled still remains,

Deep versed in books and shallow in himself.

We should read with an independent judgment and.

a critical spirit." .........-we best evince our respect for the thoughts of the author by subjecting them to our own revision"

\section{2}

The acquisition of degrees as a yardstick for teacher improvement has been the accepted medium for 10 , these many years. Ifttle recognition has been delegated to experience,travel, civic activities,or to work in other fields related or unrelated to the subjects taught.Yet.John Stuart Mill commented thusly on this

1.Milton. Parqdise Regained Book 4,Iine 322. 2.Porter, Noah. Books and Reading page 52 . 
very topic in his essay on Iiberty,"A person whose desires and impulses are his own-.........-are the expression of his own nature, as it has been developed and modified by his own culture.......... is said to have character. One whose desires and impulses are not his own has no character, no more than a steam engine has a character"

Within recent years some school systems are basing salary increases on other than scholastic advancement. Travel,writings, and experience are assuming a place of some significance as a form of education with travel and publication the more recent of the three.

Naturally, a prime prerequisite for good teaching is that a teacher possess a more than speeking acquaintance with the subject taught. The two should be old Priends. A considerable portion of that knowledge comes from reading.Gilchrist $B$. Stockton in an interview for an article entitled "What Should be the Teacher's Greatest Assets?"expressed this view."Unless a teacher has a thorough knowledge of the subject he or she is teaching, it is very difficult to succeed,even though endowed with all the other important qualifications for the exacting profession! 2

1.M111,John Stuart. On I1berty and Uther Essays,Ch.3,p.71. Macmillan Company, New York, 1926. 2.Stocktón, Gilchrist B. Delta Kappa Gamma Bulletin, p.21. Summer 1948, Vo1.XIV, Number 4. 
But neither Stockton nor the other seven persons writing for this article place subject matter as the one requirement.Indeed, he only gives it prime importance. Arthur H.Breed,Jr.in the same article says,"The primary prerequisite for a teacher should be character" Parallel that with John Stuart Mill's statement of character and the conclusion to be drawn is that reading is just one part of living and teaching.

"In reading we do well" says Noah Porter,"to propose to ourselves definite ends and purposes. The distinct consciousness of some object at present before us,imparts a manifold greater interest to the contents of any rolume. It imparts to the reader an appropriative power.......by which he insensibly and unconsciously attracts to himself all that has a near or even remote relation to the end for which he reads........-.-Indeed, one never learns to read effectively until he learns to read in such a spirit--.---with mind attent to appropriate and retain and turn to the uses of culture, if not to a more direct application"

"It is sald that Carlyle read, on an average, a dozen books a day and after long practice was able to find at once the jugular vein and carotid artery of any author!!

\footnotetext{
1.Breed,A.H. What Should Be the Teacher's Greatest Assets? Delta Kappa Gamma Bulletín, Vo1.XIV.No.4,1948. 2.Porter, Noah.Books and Reading pages 41-42. 3.Koopman, H.L. The Mastery of Books page 47 .
} 
SECTION

II

SCOPE AND METHOD OF THE STUDY 
The accusation that teachers, categorically class-ifying all teachers in one group,are a dull,uninteresting and disinterested lot is fairly prevalent among laymen. Too often it has been said that teachers do little to broaden their minds, that they teach in the same old routine established during the first years in the profession. Such statements are broad almost to the point of being extreme and ludicrous when all teachers are lumped together.Such findings may be justified concerning some in the profession as here are laggards whose strongest interest seems to be to avoid hard work as there are in any walks of life,but, to say that such is the case of all teachers is to label the spinner of such idle phrases as uninformed, if one speaks charitably; if not, to badge him as ignorant.

And so,this survey on teacher-reading does not fight the teacher's battle. Instead, it merely lists, classifies and records its findings. 
SCOPE AND METHOD OH THE STUDY

What do teachers read?hat question became a matter of burning interest to me.Did teachers read sufficient material to conduct classes on a large scope bringing to the classroom and to their students a broed fresh viewpoint or did they offer only their personal views gleaned from individual experience? So vitally important was the subject that the writer felt a survey was needed to present some definite Information either favorable or unfarorable to the teacher.

Why had this subject become a matter of such intense interest to me? Mainly was this produced by my observations that few teachers read sufficiently or as easily as they should. In truth, in ing limited experience I had found some teachers who frowned upon wide reading and who in their narrowed minds criticized much that is being written today and has been written in the past.However, I asked myself this question: "How then, if not by reading both the good and the bad,can teachers evaluate any reading?" And so,I determined to conduct a survey. 
Again, I probed myself to find an answer as to why literature or any type of reading should not be a topic for conversations by teachers when they gathered in their teachers' rooms during rest periods in their respective schools? Why should zestful young teachers be forced to conceal their eagerness for reading in order to maintain the friendship of older members of the profession? Why should a young teacher feel obliged to cover books of bold titles with somber brown paper as I once had observed? Would it not seem that even poor reading would be more upgrading than participation or lending an ear to disparaging remarks of any subject our own profeseion in particular?

Consequently, this survey is the result of such self-probing and is but a meager attempt to find the answer to all my questions.

The writer is not saying that reading is the only arenue to culture or that the teacher who does not read is uncultured, That teacher may receive more direct help from radio programs, lectures, forums, integration groups,professional meetings,group discussions, or in organizations in general and particular fields, inplays, films and in multitudinous ways. I only am saying that reading should play a part in every teacher's ilfe. 
Bacon, in his Essay of Studies said, "Some books are to be tasted,others to be swallowed, and some few to be ohewed and digestedy He did not add in his gustatory language that some should never be read at all but leaves one with the impression that he had taken the time to examine some odorous rolumes.

To conduct this survey a limited period of time was necessary, therefore, the one year period,1947-48. The writer must know the extent of their reading both as to type and quantity.Quite often the person when contacted could tell the name of the book or periodical read but not its publisher or author.Necessarily, then,1t became my task to check all recorded reading as is indicated by the bibliography.

Each teacher was given a flle card questionnaire and time to think because few of us can recall adequately on the spur of the moment the full extent of our reading. So, a second contact with the teacher was necessary in most instances.The facts obtained from these interviews had to be recorded. In some cases, a third call or interview was made to discover why the reading had been extensive or limited.

1.Bacon. Essay of Studies As ref.0Organization of Ideas"
Mchurry,F.M. page 112
2. See facsimile page 8 of this study.


My paper must take a form. The subject of teacher reading must be attacked from all angles possible.

A sample of the file card questionnaire used is shown here.

WHAT HAVE YOU READ DURING THE YEAR 1947-48?

Professional books?

Professional periodicals?

Fiction?

Non Fiction?

Non Professional periodicals?

News?

As many cards as needed by each teacher were arailable and all interviews were made within the last week of June 1948 .

No claim is made that the study is typical but the findings typify the extent and type of teacher reading resultant from a survey of fifty teachers. Usually, few popular surveys include a greater number.

Two teachers supplied the findings for each grade on the elementary, intermediate and secondary levels, and two represented each major subject in the senior high school curriculum. 
The study records the extent and type of reading of teachers for the one year period,1947-1948.Fifty teachers,twenty-five of whom were enrolled in a college class in education and twenty-five who were not,serve as the basis for the findings.

The reading has been divided into the following groups : books, professional; periodicals, professional; periodicals, non-professional; books, fiction; books, non-fiction; and news.

Information received from teachers was recorded on cards that accompanied the file card questionnatre. Cards were numbered but no name was attached.

Since this was a surrey of persons supposedily interested in education,professional books and professional periodicals received primary attention. In order to fairly present my findings concerning the Louisville and Jefferson County teachers in so far as possible the number was equalized,there being twenty-six city and twenty-four county teachers.

So, the outlining and tabulation of facts assumed a place of major importance in the study of this topic, and the writer presents in this paper the findings of the survey on What Teachers Read.Part is highly commendable to the teacher;part is not plattering and is most disappointing to me as a teacher. 
Let us take it at face value. It,at least, has served to answer the questions which long have been plaguing me.

And once again,the writer disclaims any statement that the study is typical. 
SECTION

III

FINDINGS OF. THE STUDY 
FINDINGS OF THE STUDY

The following graph substantiates the assertion made previously in this paper that some teachers do try to improve their teaching techniques or at least do endeavor to keep abreast of current educational trends. Especially is this true when it is realized that this surrey was made among teachers who were chosen at random, irregardless of their known professional zeal or its lack.

Professional Books Read During 1947-48

Teachers Enrolled

in Education Class

Teachers not Enrolled

in Education Class 25
Books Read

67

53
Total Books Read

\section{Professional Periodical Reading}

Professional periodical reading tells a rather unique story. In this group the twenty-five teachers who were not attending college classes read 123 professional periodicals while their colleagues who were attending college read ont 49. No attempt was made to determine the exact cause for this lack of periodical reading on the part of teachers enrolled in college classes.Only surmise can explain it by limited time which was devoted to required reading and that professional periodicals did not fall into this category. 


\section{Fiction}

Many people would snuff out the light of fiction with the statement, "A waste of time to read that trash" And, indeed, many so-called best sellers are as stated in The New Yorker-Book Review Section in its criticism of Ross Lockridge's Rain Iree County. "Like so many best sellers today it is fit only for the garbage can!However,some of the fiction read by teachers apparently was not just light relaxing frivolous fiction when such books as A.J.Cronin's Kers to the Kingdom and Sinclair Iewis' Kingsblood Royal were included.

The chart that follows too is revealing. Fiction Books Reed

Teachers Enrolled in College Classes 25

Teachers Not Enrolled in College Classes
25
Books Read 54

90
Total

Fiction Read

Non-Fiction Books Resd

Books of non-fiction were not slighted during the past year in teacher reading. Such books as Eisenshiml and Newman's American Iliad and E.Stanley Jones'

Christ of the Indian Roed received considerable attention. See chart below: Books Read Total NónTeachers Enrolled in College Classes 25 25 Teachers not Enrolled in College Classes 25 32 57

1 New Yorker-Book Review Section.Jan.10,1948,page 70. 


\section{Non Professional Periodicals}

Non-professional periodicals which include all magazines other than news magazines and newspapers seemed to be almost as popular as fiction books. The twenty-five teachers in college training read 92 such magazines while the other twenty-1ive read 117 making a total of 209 non-professional periodicals read.

\section{News}

Reading of news which embraces news magazines and newspapers certainly gave rise to speculation as to the necessity for college courses to include some of that type of reading in their required reading lists. The twenty-five teachers not taking college work reported that they read regularly 45 news magazines or newspapers, or approximately two per person. On the other hand, the twenty-five who were in college classes read regularly only 24, not quite one per person.Again charitable surmise would attribute this lack of reading to limited time to fulfill required obligations.

\section{Total Reading by Fifty Teachers}

Thus we arrive at the grand total of reading by fifty teachers representing their profession in Louisville and Jefferson County and also including twenty-five who were in college classes and twenty-five who were not.These fifty teachers read during the year 1947-48 a total of 771 different types of reading or 15 and two-fifths of 
a book,magazine etc.per teacher.Considering titles of reading material relative to their profession, one might be interested to know how many doctors, lawyers, or dentists could present a better record. Would not that, in 1tself,provide an interesting study?

\section{Reading on Different Teaching Levels}

Not alone were teachers divided into two groups of those who were attenaing college and those who were not.To make the study more meticulous and revealing the various levels of teaching ranging from kindergarten through grade twelve also were used.This division of the survey listed many subjects found in the juntor and sentor high sohool curricula. For findings review the chart on the following page. 


\section{Chart of Teacher Reading According to Grade Level} and Subject Taught

\section{Types of Reading}

Two Teachers on each Grade Level

Kindergarten Grade one Grade Two Grade Three Grade Four Grade Five Grode Six Grade Seven Grade Eight Grade Nine Grade Ten Grade Twelve
Prop. Books
Prof. Fiction Period-Books icals
IonFiction PeriodBooks icals

On Level of

Subject Taught

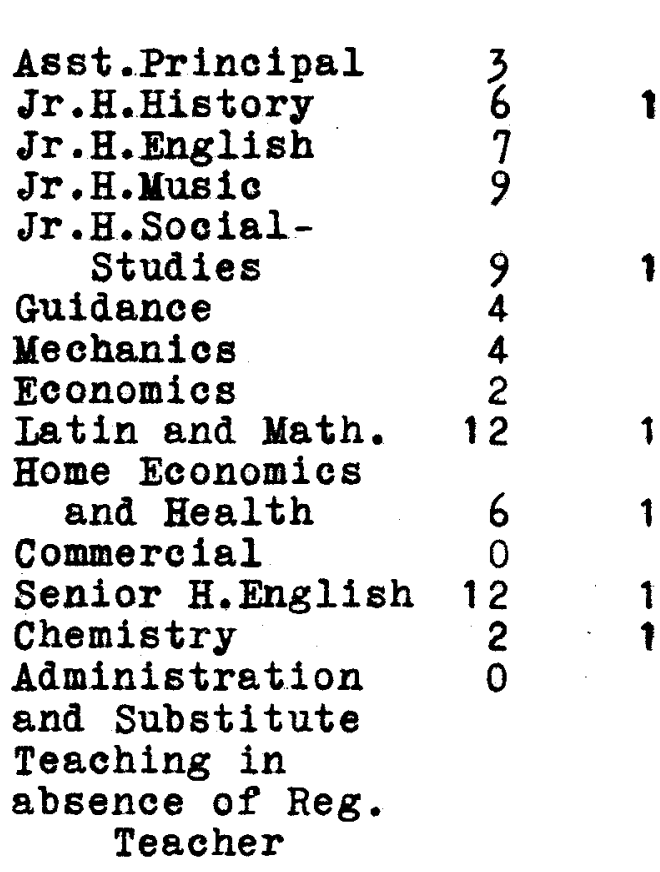

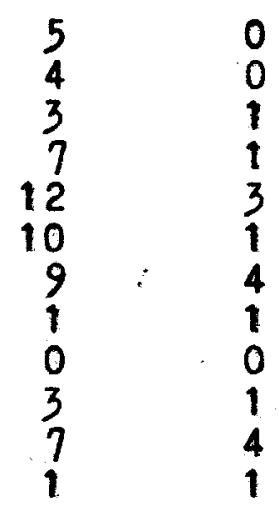

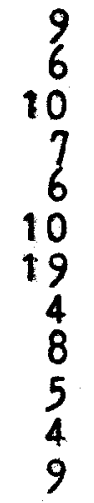

0

1

t

3

4

1

0

1

4

20

28

30

38

13

15

32

30

25
4

6

3

0
3
6
9

0
1
4

8
5
4
18

15

32

29

146

83

7

2

$\begin{array}{rr}12 & 13 \\ 4 & 0 \\ 16 & 34 \\ 15 & 4 \\ 7 & 2\end{array}$
5
6
1
3
3

30
6
25
5
3
5

37

15

18

128

13
0
34
4
2

$\begin{array}{rr}2 & 70 \\ 2 & 12 \\ 2 & 105 \\ 2 & 29 \\ 1 & 14\end{array}$


The following charts explain a further breakdown in teacher-reading. A compilation of the number read of each type of material is recorded as is the most often and least read of each of the six classifications differentiating between the teachers enrolled in college and those who were not enrolled. 
Chart of Professional Books and Periodicals Read br Teachers Enrolled in College Classes and Teachers not Enrolled in college classes

Title of Books

The Child and His Curriculum

Experience and Education Dewey

Education:America's Magic Hughes-Iancelot

Democratic Education in Practice Schneideman, Rose

"The Portable Veblen" Max Ierner

Gauging Public uplnion Cantril, $\mathrm{H}$.

Title of Periodicals

N.E.A. Journal

8

Coronet

Kentucky School Journal

National Geographic

We the People

School and Society

Teachers College Record

School Iife

Saturday Review of Literature
Teachers Enrolled Teachers Not in College Classes Enrolled in College

Classes

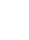


Chart of Fiction and Non-Fiction Books Read by Teachers

Enrolled in Collese Classes and Teachers Hot Enrolled in

\section{College Classes}

Fiction-Title

Teachers Enrolled Teachers Not in College Classes Enrolled in

College Classes

Kingsblood Royal

2

4

Lew is , $\mathrm{S}$.

$\frac{\text { Rain Tree County }}{\text { Lockridge, Ross }}$

3

3

Iin Flute

3

3

Roy,G.

The Bright Promise

3

3

Sherman

Zotz:

Karig

3

3

Non-Fiction

Denger From the Far East

2

2

Iauderbach

Peace of Mind

Le 1bman, Joseph

1

2 
Chart of Non-Professional Periodicals and News Read by Teachers Enrolled in College Classes and Teachers Not Enrolled in College Classes

Periodicals

Non-Professional

Readers Digest

Iffe

Time

Eortune

Cosmopolition

American Yagazine

Atlantic Monthly
Teachers Enrolled Teachers Not in College Classes Enrolled in College

Classes

News

Courier Journal

New York Times Book Review Section

Iouisville Times

New York Times

4

News Heek

U.S.florld Report

Chicago Tribune

New York Herala

0

2

Christian Science Monitor 
The results of the charts on the preceding pages reveal much concerning teacher reading. Teachers of primary and intermediate grades,kindergarten through Grade Six, read a total of 181 books, articles etc. during the year 1947-48; the four teachers of the junior high school level read 60; the four on senior high school level read 55;while the two assistant-principals and the two representing administrative steff fell far short with 15 pieces of reading accredited to the former and 14 to the latter. Would limited time explain this situation or would it seem that when a person reaches the topmost rung of the ladder ambition wanes?

Commercial and mechanics teachers represent the only groups of teachers in any way approaching the paucity of reading of the assistant-principals and the administrative staff with a credit of 12 books,periodicals etc, for the first group and 15 for the second.

Compare that tabulation with the 105 selections read by the two senior high school English teachers, the 70 by the home economics and health teachers, the 43 by the junior high school music instructors. The preponderance of reading falls to the teacher on practically each score. Again, a comparison between the two senior high school English teachers and two physioians chosen at random might prove favorable to the teachers. 
A total of reading of each grade level penetrates the subject further. In the junior high sohool division twelve teachers of six different subjects supply the information and in the senior high school division there are ten teachers representing five subjects.

Grade Level

Primary see chart page 15

Intermediate " Senior High Junier Hizh

$n$

n
Total Reading on Four Grade Levels Types of Reading Number of Teachers

Total Reading 85

8 6 12 10
96 178 250

Another interesting phase of this survey is the discovery that in the case of the two senior high school English teachers nine selections of the total 105 were read by the teachers enrolled in a college class while 96 selections occupied the time of the teacher not enrolled in college. In the home economics and health departments the teacher in a college class read 15 books,periodicals etc.while the teacher not in college read 55. But the junior high school music instructor who was in college read 34 of the 43 recorded readings.Ninety of the 181 periodicals, professional and otherwise, books etc.read by teachers of primary and intermediate grades were read by teachers taking college courses. 
Twenty-three of the 60 readings by the junior high school teachers were accomplished by teachers in college classes.Thirty-four of the 85 selections by the two teachers chosen to represent all senior high school teachers fell to the lot of teachers in college classes. In each of the three divisions the teachers not enrolled in college classes read more than those who did,particularly is this true in the last two divisions. Is this not sufficient evidence to promote a discussion as to which of the two groups, those in college or those who are not,are the better informed or, at least, the more widely read?Naturally, no attempt here is being made to evaluate the readings of each group or to balance the knowledge of one against the other.

\section{Comparison Between Reading of Louisville} and Jefferson County Teachers

The search light can be turned on this survey from still another angle, namely, a comparison between the teachers in the schools of Jefferson County and those in the public schools of Iouisville.01 the 50 teachers interviewed,24 were county teachers and 26 were in the city of Louisville.A total of 321 books, periodicals, etc.of the grand total of 771 books read by the 50 teachers were read by teachers now employed in positions in Jefferson County. The other 450 were read by the twenty-six teachers now holding positions in the Louisville Public Schools. 
Of the 321 selections of total reading by Jefferson County teachers 167 represented professional and nonprofessional periodicals. That leaves 154 readings to cover fiction and non-fiction books, professional books and news. The 154 can be broken down further by stating that 72 of this number represent professional books. And 45 of the 72 , more than half,were read by teachers enrolled in college classes.This would tend to indicate that little reading of books and newspapers is done by teachers in the Jefferson County schools except that which is required by college professors. That means that twenty-four county teachers read 27 books, fiction and non-fiction, and newspapers during the year 1947-48.

Contrast that with the record of twenty-six teachers in the Louisville schools.0f the 450 selections read 132 are professional and non-professional periodicals or not quite one-third,while this same classification represented approximately one-half of the reading of the Jefferson County teachers. And while news reading played a minor role with the county teachers,32 newspapers or straight news magazines are read regularly by the Louisville teachers. The County teachers, however, did read almost one and one-half as many professional books as did the Louisville teachers who read approximately 50 as compared with the county record of 70 . That leaves 146 books, fiction 
and non-fiction, for 26 city teachers as compared with 27 books, fiction and non-fiction, and news which were read by 24 county teachers.

Eighteen of the 26 city teachers were not enrolled in college classes. Is it not interesting to note that 32 of the professional books read by city teachers were read by the 18 not enrolled in college classes or an average of almost three professional books per teacher? The remaining six teachers read 18 books or exactly three professional books per teacher. It would seem that the reading by Louisville teachers is a bit better balanced than that by the county teachers where the preponderance lay in professional reading, of books and periodicals. Louisville left more than one-third of their reading to fiction and non-fiction books.

The appalling phase of this survey is the fact unearthed that most of the fiction and non-fiction books read by both groups are current literature, Only one classic, Thackeray's Vanity Fair, is mentioned, and the Bible as a part of regular reading is recorded but twice. No poetry is listed whatsoever.

Such magazines as Holiday, Hobbies, Ladies 'Home -Journal, etc.received scattering rotes in the survey but a close ratio of titles popular among both Louisville and Jefferson County teachers is shown in the chart on page 25. 
Chart Indicating Yagazine Popularity Among Teachers in the city of Iouisville and Jefferson County

Title of

Magaz ine

Readers Digest

coronet

Ifle

Woman's Home Companion

National Geographls

Saturday Evening Post

Hewsweek

Saturdar Review of Iiterature
Teachers in the Teachers in

City of Louisville Jefferson County
13

5

8

5

4

2

4

1

2

0 
The most widely read non-fiction books were Danger From the Far East and Peace of Mind. Each had been read by four different teachers. In the field of fiction both Rain Tree County by Ross J.Iockridge and KIngsblood Royal by Sinclair Lewis headed the list with six persons having read each book. Next, with five readings were A President Is Many Men by Smith and Gentleman's Agreement by Hobson. Appearing in third place with four readings each were Miracle of the Bells by Janney, captain from Castile by Shellabarger, and B.F.'s Daughter by Marquand. The following table gives the number of readings of each of the classifications that were tabulated in the survey.

Type of Reading Material

Fiction

Non-Fiction

Periodicals Professional

Periodicals fon-Professional

News

Books Professional
Number of Volumes Tabulated in the Survey

71

38 36 43 9

58
Total Number of Readings of Each Classification

144

57

172

209

69

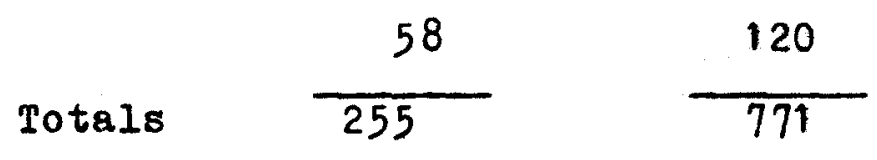

The above table furnishes rather conclusive proof that teachers are reading; maybe not as much as would be desired but, nevertheless, they are reading. 
As was stated earlier in this paper many factors influence the extent of reading.One teacher who commented on her card,"I'1I plead gullty of doing very little reading" offered these reasons for her dearth of reading."I drive twelve miles to school, support two daughters who are in high school and require much sewing.I confine my reading to the preparation of class lessons and I help my own daughters so that they may have the time to keep in touch with current news!

A commercial teacher whose readings were limited to three periodicals (professional) and eight non-professional periodicals said,"I am a commercial teacher by day and the same by night"

A mechanics teacher who has read only one professional book and two periodicals stated,"I am so busy trying to secure a degree in engineering and working also that there is hardy a moment to live!

All these are valid explanations for little reading. The human element cannot be overlooked in the teaching profession any more than in any other profession.Jacques Barzun suggested in his latest edition that teachers learn what to let $X$ equal. The writer concludes that most teachers must let $X$ equal time and work a life time for its solution. "Suspended Reading"the volumes upon volumes that teachers reported,"I am going to read when I have time", would surely please the publishers. 
Nor is the teacher who reads considerably one-sided. It was found thet several such instructors are members of various civic clubs such as the Louisville Woman's Club, the Business and Professional Woman's Club, the Delta Kappa Gamma Educational Sorority and others.These teachers in many instances attended concerts and plays,play in the Iouisville Philharmonic Orchestra or participate in churoh activities. However, no definite figures can be given to indicate how many of these fifty teachers so use their leisure time. 


\section{SECTION}

IV

CONCIUSIONS DRAWN FROM FINDINGS 
IV

\section{CONCLUSIONS DRAWN FROM THE CHART AND SURVEY FINDINGS}

Many conclusions emerge as a result of the findings of this paper. The one most outstanding is the fact that the classics and the Bible should be read more widely by teachers.They with poetry are neglected both by teachers whose time is filled meeting the required reading as set down by college professors and by those teachers who are at liberty to choose their own selections.

Secondly, the teachers of Jefferson County are trailing their colleagues in the Louisville Schools. The explanation that quickly comes into our minds in defense of the county teacher is that in the junior and senior high schools of the city there are well equipped libraries which make reading material easily available to the city teacher.Free periods can be spent in browsing through the new books just received or in reading periodicals or books.Teachers also have the liberty of checking out these books which eliminates the necessity of making a special trip to a public library to obtain material.0ften these public libraries are too far distant from the county teacher's school or home. Third, that the classes of the teachers who do little 
reading cannot be as rich in content as are those of the teacher who is more widely read.

Fourth, that teachers should learn to paragraph or page-read books for relaxation.Too often,an excess of time is required in reading uninformative materlal. Teacher-training classes might add sight or skim reading as a course in the curriculum.

From the findings of the chart and reviews studied by the writer in the bibliography readings it is concluded that too few newspapers are read regularly by the teachers and especially so in the history and social science departments so representative of current readings.As a whole one would surmise that they are as widely read as are persons in other professions and that college courses limit the time that the teachers have for wide reading. From the interviews recorded in the study regarding wide or limited reading factors,personal problems of time, distance and accessibility of reading material of the teacher's cholce or need seemed predominant.

The recordings show for the most part that reachers make some effort to keep abreast of current educational trends and are conscientious about giving value received for their increases in salary for the positions they recorded in interviews do not, in many instances, require aditional professional credit hours. 
While making the interviews and recording the findings many recalls were necessitiated and the writer was impressed with the statements indicating that most teachers hold reading in high regard as a pleasure and pastime as much as a professional duty and for needed information in general. They sincerely indicated that they read as much as time and circumstances permit, and that they regret their inability to read more. 
SECTION

V

SUGGESTIONS FOR CONTINUED STUDY 
SUGGESTIONS FOR CONTINUED STUDY

Some suggestions for further study that could be classified as an outgrowth of this study are easily discernible.It would be most enlightening to ascertain just how much the widely read teacher influences and enriches her classroom lessons with her readings as contrasted with the teacher who has no interest in anything other than teaching techniques.

Also, how interesting could be a study of just how the comic books and comic strips in the newspapers could serve as alds in teaching. One teacher not named in this survey stated,"I often use comic books on the classics to arouse interest in literature. To me,they have a place as do recordings. From the comic book or comic character I lead my class into literary selection. By comparison they can evaluate the poor quality of the comic bonk. Yet,it serves a very pronounced purpose" Here, thought the writer as she observed the erudite attitude of the vivacious teacher, is one the children can set their hearts by. Stepping down, so to speak, she accepted information from the children in their area of understanding. Her attitude it would seem, could be an unvoiced invitation that encouraged the students to ask for advanement into her area of learning, finding as they advanced, 
improved abilities in evaluations.

On the date of the inspiring interview described, the writer read with moments of foreboding, the following statement in the dally news: "Many, many eminent psychiatrists have been testifying in interviews, on the radio and in magazines on the subject-'Do comic books affect morals of the young? 1..........-A large number of Americans read more comics than anything else, and vast numbers of adults read them,constantly, American culture and morals will be affected, and not for the better" Comic-Topic attitudes were not observed in the classes taught by the psychologist and psychiatrist at the University of Louisville in which the writer was enrolled. The attitude of the teacher who guided her classes from within rather than from without,as described on the previous page was predominate in their instruction.

It would seem that good learning, or any learning, must not be accompanied by self-reproach, if we are ashamed of what we know at any level of learning, how could we add good to bad and have any sum worthy to be called the foundation of learning? In the writer's point of view Emerson describes pure knowledge and a true attitude of learning-situations in his essay on Self-reliance; "What

1.The Iouisville Times Aug.13,1948,page 8. 2.Dr. Noble Kelly, Psychological Center, University. 3.Dr.Charles H.Crudden, Nichols Hospital. 
oracles nature yields us in the face and behavior of children,babes and even brutes, they are as yet unconquered, and when we look into their faces,we are disconcerted. Infancy conforms to nobody;all conform to it;its claims are not to be put by.God has armed it with'individuality' the healthy attitude of human nature" Then comes school-age and conformity, if possible.Repressive -teaching, the method of annihilating individuality, is fast giving way to the unfoldment method through out the educational system. It would be interesting to know how directly proportional conformity may be to the progress of retarded learners.

As the suggestions for continued study derived from the flndings of this paper are being typed a bold caption, "Teachers Unfit to Solve Child's Woes" strikes the typist very uncomfortably physically as the morning paper is hurled in her direction by the junior-high-age carrier. What teacher has boasted such fitness? A study of the carrier's reading might reveal the energizing source of his deliveries.One surmises the English-teacher's ascending technique described on page 32 presents proof of the children's fitness for solving woes on the path of procedure to introducing the classics.Dr.LaPorta goes on to say in her article that 3

1.Emerson.Essay on Self-reliance page 147. 1940

"The Writings of R.W.Emerson", The Modern Library,N.Y 2. Courier-Journal, Aug. 14,1948 , page 7 .

3. International Conference on Child Psychiatry, London. August-1948. 
teachers, too, have woes beyond their ablilty to solve and that they are often neurotic and ill from overwork as are some of the parents.This view emphasizes the need of a psychological center for the parents and teachers before they are permitted to accept the positions of "fitness" to aid the children in solutions to their woes.

A survey of reading by members of other professions and its comparisons with the findings in this paper would provide a study of more than passing interest.

A five-year study of Teacher-Reading would offer sufficient material for a thesis and its findings certainly would be far more complete than are these in this paper which cover only a one-year period. 
BIBIIOGRAPHY$$
\text { - }
$$ 


\section{BIBIIOGRAPHY}

Books

Alexander, Carter. How to Iocate Educational Information and Data

Teachers College,Columbia University

New York, 1941 .

Croxton,Fredrick. General Statistics Ch.VI,IX.

Prentice Hall, New York, 1942 .

Dewey, Melvil.

Decimal Classification and Relative Index with Supplement

Wilson Company,N.Y.,1942 (revised edition)

Library of Congress A Certiflcation of Books Represented by Printed Cards

Library of Congress,1942. (Title, Author,publisher, editor and brief of the volume.)

Wight, Edw.A.

Wilson, Iouis $R$. County Iibrary Service in the South Ch.IV,V,VI.

Chicago: University of Chicago Press 1939

Waples, Dougles and Carnorsky

Iibraries and Readers in the State of New York Chicago:University of Chicago Press 1939

Kunroe, Ruth. Gray,W.S.

The Reading Interests and Habits of Adults

Macmillan Company, N.Y., 1929

Buswell, G.T.

How Adults Read Chlcago:University of Chicago Press 1937

Stuart,Chase.

The Tyranny of Words Harcourt, N. Y. , 1938 
Books

Gates,A.I.

Burks , B.S.

Gray, W.H.

Brooks, F.D.

Monroe, $\mathrm{X}$.

Index

n

Kieran, John

(Eaitor)

Adler,Mortimer $\mathrm{J}$. $\frac{\text { Psrchology for students of }}{\text { Macmillan, N.Y.,1938 }}$

The Relative Influence of Nature and Nurture Upon Mental Develop-ment

National society for the Study of Education, Twenty-seventh Yearbook Ch.X,Part I, 1928

Psychology of Elementary School

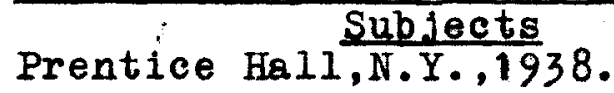

The Anplied Psychology of Reading Appleton Century Company,N.Y.,1936

Chilaren tho Cannot Read University of Chicago Press, 1932

Education Index

H.W.Wilson Company

950 University Avenue, N.Y.

Cumulative Book Index (1929)

A world list of books in the English

language and publicetion dates of

translations-Mann, Thomas. The Magic

Mountain and the Buddenbrooks.

Information Please Almanac (1947)

This volume was most helpful in locating books whose readers recalled and recorded the content better than the author and title of their reading. Doubleday, N.Y.

How to Read a Book

(The Art of Getting a Liberal Education)

Simon and Schuster

New York 
Clarke, James

Eurich,A.C.

Ioveman, Amy

Pitkins, Walter

Index

Committee on College Reading

Dickinson,A.D.

Waples, Dougles, Tyler, Winfred.

Wilson, I.R.

Prescott, D.A.

Preston, G.H.
In the Ianguage of the People (the practice of book selection) Chicago: University of Chicago Press pp.179-89. 1940

The Reading Abilities of College students (an experimental study) Minneapolis: University of Minnesota Press, 1931 .

"I'm Looking for a Book" Dodd Publishing Co.N.Y., 1937.

The Art of Rapid Reading McGraw-H111,N.Y.,1929.

Cumulative Book Index H.W.Wilson Company, $\bar{N} . Y$.

Good Reading

The National Council of Teachers of English,Chicago, Ill.

Best Books of the Decade H.W.Wilson, N.Y.1937.

What People Want to Read About Chicago: American Library Assn.Press. 1931

The Geography of Reading Chicago: University of Chicago Press 1938.

Emotion and the Educative Process Am. Council on Educetion, 1938.

The Substance of Mental Health Rinehart and Company,N.Y.,1943 
Periodicals

Am.Ed.R.Assn.

Delta Kappa

Gamma Bulletin

Hall, W.E.

Sohon, Julius

Social Forces

Magazine

Bidwell,Percy Wells

Briggs, E. Stephen

Bryan,Alice Isabel
Teacher Personnel

"Review of Educational Research" Vol.13,No.3, June 1943 through " 16 " 3 , " 1946

N.E.A. $\quad 1201$ 16th.St.,Wash.D.C.

What should be the Teacher's Greatest Assets?

Vol.XIV, Ho.4Summer 1948

M.Margaret Stroh, Editor

804 Littlefield Building

Austin 15, Texas

The Role of Reading as a Ilfe Activity in a Rural Community Journal of Applied Psychology Vol.XXVI,1924 pages 530-42.

The Correlation Between Economic Trends and Library Statistics in Bridgeport, Connecticut

"Workers and Readers"

Iibrary Quarterly,Vol.XI,1941 pages $334-356$.

Educational Status and Its Relationship to Reading and Other Activities

Vol.XVIII,1939. pages 56-59.

Readable Writing

Jr.of Adult Education

Vol. 7,p.389-92, Oct.1935.

Reading Interest and Habits of Adults

School and Society Vol.42.

July 6,1935.page 20-21.

Personality Adjustment Through Reading

Iibrary Jr.,Vol.64,Aug.1939. pages $573-76$. 
Periodicals

Bryan, Alice Isabel

Carnorsky, Leon

Carnorsky, Leon

Eels,W.C.

Ferguson, C.W.

Gooding, Lydia Marian

Hoole, Wm.S.

Hunter, Elden

Kreig,Laure I
The Psychology of the Reader Library Journal Vol.64, Jan.1, 39. pages $7-12$.

Community Studies in Reading Library Quarterly, Vol.5, Jan. 35 .

A Study of the Relationship Between Reading Interest and Actual Reading

Iibrary Quarterly, Vol.4, Jan.'34. pages $76-110$.

What Periodicals Do School Pupils Prefer?

Wilson Bul., Vol.12,Dec.1937. page 248 .

Educating the Emotions

Am.Iibrary Assn.Bul., Vo1.3, Aug. 137 pages 433-41.

Reading Interests of College Students

Library Journal, Vo 1.59, Dec.1, 134 pages $921-23$.

A Survey of the Reading Hablts and Ilbrary Usage of Birmingham Southern college Students. Peabody Journal of Education Vol.5,Jan.1938.pages 216-220.

A Study of the Periodical Reading Done by College students

School and Society, Vol.40,July 14: 1934 , pages $70-72$.

Community Studies in Reading L1b.Quarterly, V01.9, Jan.1939. pages $72-86$. 
News

Grumette, Jesse

U.S.Office of

Education

Ayer, N.W.

Ulrich, Carolyn F.

Faxon

Heràld-Tribune Review

New York Times Review

Muir, Malcolm (editor)
An Investigation into Newspaper

Reading Tastes and Habits of High School Students

"High Points" Vol.19,Dec.1937,p.5-10. A publication by the Board of Education, Brooklyn, N.Y.

Bibllography of Research Studies in Education (bulletin)

Washington Government Printing Office.1926-27 to date.Annual.

Index to Newspapers and Periodicals N.W.Ayer and Son's (Index)

Philadelphia, $\mathrm{Pa}$.

Periodicals Directory

Published every three years(1932)

R.W.Bowker and Company, N.Y. (zone 6)

Faxon, Iibrarian's Guide

(magazine specialists)

83-91 Francis street

Boston, Mass.

New York Herald Tribune Book Review

230 West 41 Street, New York 18, N.Y. (weekly)

New York Times Book Review

229 West 43 rd.Street, New York 18,N.Y. (weekiy)

News Week

152 West 42 nd.Street, New York 18,N.Y. 
News

U.S. News

U.S. News and World Report (1933) United States News Publishing Co. 24th. and N.Streets N.W.

Washington 7,D.C. Mccormick, Robert R.
(editor)

Wallace, Tom (editor)

Bingham, Barry (editor)

Merz,Chas. (editor)

C.Science Publishing Company
Iouisville Times (Est.1884)

Member of the National Newspapers Alliance.

Courier and Times Building

Sixth and Broadway

Louisville 2 , Kentucky

Courier Journel (Est.1826

Courier and Times Building

Sixth and Broadway

Iouisville 2, Kentucky

(daily andsunday)

New York Times (Est.1861)

209 West 43 rd. Street

New York 18 , New York

(daily and Sunday)

The Christian Science Monitor

(Est.1908)

The Christian Science Publishing Soclety

One Norway Street,Boston 15,Mass. 